idmitted to the Spa on the production of their tickets. It has also been arranged that the train shall stop at Castle Iloward to enable any members to pay a visit, but it is understood that only a portion of the house and gardens will be available.

Harrogate, Brimham Rocks, and Pateley Bridge: conductor, Mr. W. Ingham.

Ripon, Studley Park, and Fountains Abbev.-The Marquess of Ripon has kindly promised to entertain a party of about 100 to luncheon, and the Mayor of Ripon will entertain the same party to tea.

Ilkley and Bolton Abbey.

Coxwold, Byland Abbey, Helmsley, Duncombe Park, and Rievaulx Abbev. - It is expected that the party will be entertained at Duncombe l'ark by the Farl of Feversham; conductor, the Rev. C. N. Gray.

Wensleydale; conductor, Mr. W. Horne.

Mount Cirace, Cruisborough, and IVhorlton Castle.-Admiral Challoner has kindly invited the party to dinner, and it is expected that the Iord-Lieutenant of the North Riding will provide luncheon; conductor, Mr. F. J. Munby.

Driffield, Kirkburn, Wetwans, \&c.; conductor, the Rev. E. Maule Cole.

Aldborough and Boroughbridge.-Three steam launches have been engaged to convey the party; conductor, Mr. A. S. Lawson, who will provide luncheon and tea.

A small guide-book will be prepared for each of the above excursions. It is understood that there will be also the usual semi-private excursions arranged in connection with several of the sections.

The exhibition of South African photographs taken by the members last year promises to be of much interest. There is ample accommodation for it at the reception room, and an active committee has the matter in hand.

\section{KEW PUBIICATIONS.}

THE "miscellaneous information" supplicd from the Royal Gardens at Kew has ever been welcome to botanists and to those concerned in the utilisation of vegetable products. The earlier publications of Sir William Hooker and of his son and successor, Sir Joseph Hooker, are full of interesting matter with which the botanical and horticultural Press of the day was, owing to limitations of space, hardly able to cope.

Of late years such was the pressure of administrative duties that the publication of the Bulletin became very erratic. So much was this the case that we had almost given up the hope of seeing anything but "appendices" to volumes that seemed never destined to appear. In this we were mistaken. Within the last month or two we have received for notice the Kew Bulletin for the years 1900 , 1901 , 1902, I903, I904, and 1905.1

Some of these volumes are of exiguous proportions, but there they are, and the troubles of librarians and bibliographers are, in so far, set at rest. Much of the information is, of course, far from being up to date, and in some cases the gentlemen mentioned as having been appointed to fill certain positions have paid the debt of Nature before their nomination has thus been made public.

In spite of these circumstances we can but rejoice that the publication has been resumed, and that the sequence of the volumes is no longer interrupted. The contents are so "miscellaneous" that they do not lend themselves to anything like systematic review. We can only put the books on our reference shelves and welcome the fact, not only that the old gaps are, to some extent, filled up, but that there is now crery prospect of the regular issue of that Bulletin to

1 "Bulletin of Miscellaneous Information." Royal Botanic Gardens, Kew. (H.M. Stationery Office, 19(x)-05.)

No. I 912 , VOL. 74] which we look for an official record of the manifold and most important work done at kew.

A "Catalogue of Portraits of Botanists Exhibited in the Museums of the Roval Botanic Gardens, Kew," by Mr. James I). Milner, clerk and acting assistantkeeper and secretary to the National Portrait Gallery, has also just been published. The catalogue is introduced with a preface by the late director of the Royal Gardens. To botanists it forms a very interesting, but, we must add, a very inccmplete list. Kew probably possesses a nuch larger number of portraits. than are here mentioned, so that it is difficult to understand on what principle the selection has been made. 'The words " exhibited in the museums" do indeed imply that there are other portraits not thus displayed, but unless we are mistaken, or unless some re-arrangement has taken place recently, there are not a few hanging on the walls of the museums which are not included in the list. At any rate, we look in vain for any mention of the Balfours, father and son, of John Ball, of Broome, Babington, B. C. Clarke, Casimir de Candolle, W. T. Thiselton-Dyer, Eichler, Engler, A. Dickson, Farmer, Gardiner, Munro, Miers, Prain, Reichenbach, Seemann, Williamson, and many others whom it would be tedious to enumerate. No doubt many of these are "kept in portfolios," and can be inspected on application, but the absence in the catalogue before. us of even the names of these more or less distinguished botanists grives an impression of serious incompleteness which is probably not justified by the facts. This is the more unfortunate as the collection is stated to be "probably unique." If so, the catalogue is very inadequate, as maty be seen, not only by the few illustrations we have cited, but also by comparison with Dr. Wittrock's much fuller "Catalogus Stockholmiensis." The text. too, requires revision. In one place we are told of a bust wearing spectacles, and of another bust " in a ruff and fur-lined coat." On another page we are told of a botanist who graduated eighteen years before he was born!

There are other indications of imperfect proofreading, to which we direct attention in the hope that the defects may be remedied in a subsequent edition. The catalogue, even in its present condition, is of such rreat interest that we cannot doubt that no long time will elapse before a second edition is called for, and one which can readily be made more representative of the progress of botany, especially in our own country.

\section{BARON C.R. VON DER OSTEN SACKEN.}

SYSTEMATIC entomology has sustained a great loss by the death of Baron Osten Sacken, as announced in NATLRE of MaY 31.

Baron Osten Sacken was born at St. Petersburg on Augrust 21,1828 , and at the age of eleven his interest in entomology was aroused by his meeting, at Baden-Baden, a young Russian entomologist, Mr. Shatiloff, who gave him his first instructions in collecting Coleoptera. Between 1849 and 1856 he held an appointment in the Imperial Foreign Office, and published papers on the re-classification of the Tipulidæ, as well as a list of the insects of the St. Petersburg district excluding Lepidoptera. His appointment, in 1856 , as secretary of the Russian Legation at VVashington opened up the second period of his entomological career in the Linited States. In I862 he was appointed Russian Consul-General at New York, a post which he resigned in $187 \mathrm{I}$, remaining, however, in America until 1877 .

During this period of twenty-one years the main 
part of Baron Osten Saclien's entomological work consisted in working up the Diptera of North America, in close collaboration with Dr. H. Loew. This work had for its main object the compilation of a catalogue of North American Diptera of which a first edition was published as early as 1858 by the Smithsonian Institution. It was superseded by a far more complete second catalogue published twenty years later. A great deal of further time was taken up with the self-imposed and, at times, somewhat tedious task of editing and translating Loew's monographs, and, in addition, important papers were published on the Tipulidæ, Tabanidæ, Cecidomyidæ, and Cynipidæ. Between $\mathrm{I} 87 \mathrm{r}$ and 1873 some time was spent in Europe, and in 1876 an expedition was made to California the results of which were published under the title "Western Diptera" in the Bulletin of the U.S. Geological and Geographical Survey. Eleven new genera and 137 new species were described.

In 1877 Baron Osten Sacken came to Europe, and took up his abode at Heidelberg. The present writer first met him there in the summer of 1877 , and, being greatly interested in entomology as a hobby a close friendship sprang up, which soon became a friendship for life. In the years which followed and which constituted the third period of his entomological career, Baron Osten Sacken published numerous critical papers on Diptera, and increased the number of his published writings from 53 to $\mathrm{I} 79$. In $\mathrm{I} 88 \mathrm{I}$ he published "An Essay on Comparative Chæototaxy," in which it was shown for the first time that the arrangement of the bristles on the bodies of Diptera afforded a valuable aid to their classification. In 1892 he published one of his most important papers, on the characteristics of the three divisions of Diptera, Nemocera vera, Nemocera anomala, and Eremochæta, in which two important innovations were introduced, one referring to the preservation of the distinction between the Brachycera and Nemocera, the other to the grouping of the families of Diptera into larger groups, for which he subsequently adopted Comstock's name of "Superfamilies."

The "Bugonia" superstition of the ancients regarding the production of bees from the carcases of dead animals found a ready explanation at Baron Osten Sacken's hands in the close resemblance to a bee of the common drone-fly, Eristalis tenax, the larvæ of which live in putrescent matter. In the paper, first published in commemoration of the twenty-fifth anniversary of the Italian Entomological Society in 1893 , and afterwards amplified and printed at Heidelberg. Baron Osten Sacken traces in detail the history of the Bugonia in different ages and nations.

His last important task was to publish a "Record of My Life-work in Entomology," which he comcluded in 1004, to quote his own words, "at the age of seventv-six, in good health, and with unimpaired eyesight."

Baron Osten Sacken took great delight in everything connected with mathematics, especially historical points, and the present writer has an early recollection of a question he proposed relating to the conchoid of Nicomedes. In his later years he made a collection of photographs of paintings of the great masters, and it gave him pleasure to arrange and classify them with the same systematic attention to minute detail that he had so successfully brought to bear on the classification of the Diptera. In his manner of living he was equally methodical, and this spirit is shown in the publication of his " Record." His interest in the work of others won for him many friends, who will greatly miss him. He has given us an excellent example of what can be done by a man who cultivates some branch of science for its own sake, and who is not debarred by pressure of professional duties from making the study his life-work. For such workers, biological rather than physical subjects in many cases offer the most promising field.

G. H. BRYAN.

\section{NOTES}

Prof. G. von Neumayer, who celebrates his eightieth birthday to-day, will receive the congratulations of many meteorologists and other scientific workers. Nearly a year ago the first part of a third revised edition of instructions and notes on scientific observations for travellers, edited by him under the title "Anleitung zu wissenschaftlichen Beobachtungen auf Reisen," was published, and the last part appeared very opportunely a few days ago. The work has been brought up to date, and is of such a comprehensive nature that justice cannot be done to it in a hurried notice, but we hope to deal with this important contribution to scientific literature in a future issue.

Mr. W. DE Fonvielle informs us that Mr. W. Wellman and his balloon-the United States-have left Paris for Spitsbergen by way of Antwerp, where the balloon was shipped to Tromsö, and from there to Magdalena Bay, lat. $79^{\circ} 40^{\prime} \mathrm{N}$. (Danes Island). The last part of the voyage will be executed on board the Fritiof, a steamer put at the disposal of the explorer by the American Government. Mr. Wellman hopes to be in Tromsö before June 25, and at Danes Island on July I. There he will find everything ready for the inflation of his large balloon, measuring 6300 cubic metres, and having a gross lifting power of 7000 kilograms. The necessary preparation will be made by Major Hearsey, of the U.S. Weather Bureau, who left Paris a month ago in order to erect at Danes Island a shelter where the balloon may be housed during the preliminary experiments, which are expected to occupy the whole of July. It is only in August that the departure for the Pole is to take place, if the experiments have proved satisfactory and have been concluded. Mr. Wellman is travelling with $\mathrm{Mr}$. Collardeau, a French chemist, and $\mathrm{Mr}$. Hervieux, a French aëronaut, who is to be the pilot of the polar balloon. In addition to Mr. Wellman, the balloon will have on board Major Hearsey, Mr. Hervieux, and two Norwegian sailors who assisted him in his two previous explorations. A wireless telegraphy system will be established between the two stations of Tromsö and Danes Island. A meteorological station will also be established at the same places, supplied with a captive balloon for obtaining records of the temperature, humidity, direction and force of the wind in the free atmosphere. So for the first time since telegraphy (wire) was utilised in meteorology, American and European meteorologists will have at their disposal observations of the weather in the neighbourhood of the North Pole as well as from tropical stations.

THE second of the two annual conversaziones of the Royal Society was held as we went to press last night.

Mr. W. R. Cooper has accepted the position of editor of the Electrician in succession to Mr. F. C. Raphael, who will retire on June 30 .

IT is stated by the British Medical Journal that the institute for the experimental investigation of cancer at Heidelberg is now complete. Prof. Czerny is the director; Dr. von Dungern has been appointed head of the scientific department, and Dr. von Wasielewski head of the department of parasitological research. 